\title{
Meninos no espelho
}

Marcelo Mattos ${ }^{1}$

O mar espelhou meu rosto. Me vejo, mas não reconheço as marcas de expressão. O mar não envelhece, águas claras batendo em minhas pernas firmes. Eu, ao contrário, vou movendo meu reflexo no tempo, vincando meu sorriso. E, tal qual anti-narciso, procuro outro rosto no mar. O meu já não me responde, procuro um menino.

$\mathrm{E}$ acho. Um menino chegou à espreita e repetiu meu gesto. Cabeça-baixa pro mar e nada via. É peixe, tio? Tentei dizer que eu me procurava, mas não havia reflexo em meu frustrado diálogo existencial. É peixe. Passou por aqui e foi para o Rio. Tem rio, tio? Aqui não é mar, é baía? O Rio maiúsculo, expliquei sem sucesso. A cidade que fica lá do outro lado.

Ah, sei. Sorte do peixe sair dessas águas sujas, nunca saí. Olhos nos olhos. Olhou-me fixamente e, no fundo, pensei ter visto meu próprio rosto. Às vezes ficamos presos à terra como plantas, com as raízes fincadas para sobreviver. Mas também somos peixes, temos ânsia de partir. Eu, homem, ainda não percorri os caminhos do mundo. Éramos dois, eu e o menino, a querer atravessar o mar.

Por que não foi? Ninguém te levou? Olhei bem o menino e vi suas origens, quebrei a lente do espelho que nos unia e o vi em diferença. Menino tem dez anos, caçula de família grande. A mãe cria seis filhos e trabalha na casa de uma tal Dona Ana. O pai pescador foi pela correnteza, um dia, a sereia levou. Mãe diz foi a piranha, mas sei, foi sereia mesmo. O dinheiro curto é para comer e ir pro trabalho, dá pra

\footnotetext{
${ }^{1}$ Doutorando em Literatura Comparada, UFF/RJ.Contato:marcelobmattos@globo.com
} 
nada mais não. Os meninos vão pra escola perto de casa, andando com aquele tênis furado com a sola colada três vezes. Sabe aquele? Diversão é só ver o mar, imaginar além do limite. Um dia vou comprar um barco só pra ir lá, vou levar meus amigos, que também nunca viram do outro lado.

Os meninos querem conhecer o Rio, nunca atravessaram a ponte, nunca pegaram a barca, nem em barcos de pesca nunca chegaram até lá. Veja o absurdo! Os meninos veem a cidade do outro lado e, como prisioneiros, não podem alcançá-la. Veem-na pelas novelas de TV, ouvem falar de suas belezas, sabem de seu renome... Ela está ali, é só atravessar! Somos nós diante dos nossos limites - disse a um amigo, convencendo-o a se juntar a mim em excursão. Levamo-nos e estaremos, nós, transpondo as fronteiras.

Podemos ir. Vamos? De carro, que barco o tio não tem. A mãe autoriza, vieram os amigos. Adultos na frente e crianças atrás. Liga o rádio, tio. Põe um funk aí. Rádio sim, mas funk já é demais. Que música é essa, tio? Vejam a paisagem, daqui da ponte dá para ver o Cristo. O Cristo vivo, tio? Não, o Redentor, monumento que fica no alto do morro do Corcovado. Ah sei. Não acharam bonito? É sim. Belas paisagens não falam aos meninos...

Aqui é o Aterro do Flamengo. Eu sou flamengo, tio! Mengooo, mengoo... É o bairro, meninos! O time fica na Gávea. Lá é a sede! Eu to com sede, tio. A gente bebe alguma coisa quando chegar no Pão de Açúcar. Oba, to com fome também. Pão de Açúcar é o morro. Aqui só tem morro? Quem quer refrigerante? Quem quer água? Sanduíche? Salgadinho? Vamos logo, se não fica tarde.

Os meninos pareciam não ver o que víamos. É assim quando se é criança: as coisas parecem distantes, quando inúteis sob o prisma lúdico. Isso serve para quê? - pareciam dizer, nas entrelinhas. Era o subtexto do desprezo que prestavam às paisagens postais da cidade maravilhosa. Estavam comportados os meninos, mas ausentes. Criança é mesmo estranha. Afinal, não realizavam um sonho? O menino, então, me enganara quando disse querer conhecer a cidade do Rio de Janeiro? 
Pois se, diante dela, fechava os olhos no interior do carro, conversando com meninos que eram como irmãos!

Aquele é o Cristo. Ah, sei! Alto! Bonito, não é?? É, tio. Vamos continuar... Copacabana, Ipanema, Leblon, aqui é a Lagoa Rodrigo de Freitas. Olhamo-nos, eu e meu cúmplice, derrotados em nossa boa intenção de agradar. Cansávamo-nos, em nossa árdua atuação turística, como professores primários a querer ensinar as lições da gramática ou a tabuada de multiplicação. Olhem! Vejam! Atenção, meninos! As cabeças estão longe, vão receber anotação, ficar de castigo! Nós, mestres impotentes, queríamos o improvável: o interesse natural!

Já estávamos a caminho da Barra, o último ponto do roteiro a ser mecanicamente cumprido, quando notei o silêncio no carro. Súbito, orquestral, tal como pausa precisa na pauta musical. Em coro, o silêncio. Olhei pelo retrovisor e vi os meninos, olhos fixos para a frente, um ponto muito além do carro. Brilhavam os olhos dos meninos, como antes não havia. Não respiravam, mas as bocas entreabertas denotavam um suspiro semântico. De repente, o sopro: Noooooossssssa! Coral afinado. Olhei à frente, acompanhando o alvo dos meninos, e notei que se erguia a imagem da Rocinha, a maior favela do Brasil. Essa é a famosa Rocinha, tio? É aqui, sim. Palavrões exclamativos se seguiram, nada ofensivos, mas dispensáveis a este acadêmico narrador com recursos de substituição lexical. Incrivel, fantástica, fenomenal! Freei o carro para que o monumento pudesse ser visto com calma e fiz a volta ali mesmo, diante do cartão postal carioca mais lindo, visto pelas retinas dos meninos da favela lá de perto de casa. São como nós, esses meninos. Procuram sempre um lugar para chamar de seu.

Liga o rádio, tio? Ligo. Qual a estação que toca funk? 